\title{
Dividend announcement effect analysis before and during the COVID-19 pandemic in the Indonesia Stock Exchange
}

\author{
Robiyanto Robiyanto $^{1}$ (D) Fanny Yunitaria ${ }^{1}$
}

Received: 17 August 2021 / Accepted: 16 December 2021 / Published online: 20 January 2022

(c) The Author(s), under exclusive licence to Springer Nature Switzerland AG 2022

\begin{abstract}
The emergence of the SARS-CoV-2 or COVID-19 pandemic has become a challenge for the global society, including the investors in the capital market, due to the uncertainty it has caused. In relation to the phenomenon, this research aimed to examine the impact of COVID-19 pandemic on the dividend announcement effect in Indonesia Stock Exchange by comparing the market volatility around the dividend announcement date of the selected stocks in 2019 and 2020. Implication of dividend increase and decrease as well as stock-risk profiling is also added for further learning. This research used event study methodology as a tool to analyze the data of the 23 sample companies taken from the LQ45 index. The period of analysis is ranged from 10 days before the dividend announcement to 10 days after the dividend announcement date. The study discovered that in 2019, the capital market presented a weak response toward the event, indicated by the inexistence of abnormal return. Moreover, in 2020, the dividend announcement effect caused negative insignificant abnormal returns and the number of companies with low volatility increased, which implies that the stock market is more pessimistic during the pandemic period. Even when the dividend amount increased from the previous period, the market still shows a negative reaction to it in 2020 .
\end{abstract}

Keywords Event study methodology · Dividend announcement · Abnormal return · Market reaction $\cdot$ COVID-19 pandemic $\cdot$ Indonesia stock exchange

JEL Classification $\mathrm{G} 11 \cdot \mathrm{G} 13 \cdot \mathrm{Q} 02 \cdot \mathrm{C} 22$

Robiyanto Robiyanto

robiyanto.robiyanto@uksw.edu

Fanny Yunitaria

212018501@student.uksw.edu

1 Faculty of Economics and Business, Satya Wacana Christian University, Jl. Diponegoro 52-60, Salatiga 50711, Indonesia 


$\begin{array}{ll}\text { Abbreviations } & \\ \text { AAR } & \text { Average Abnormal Return } \\ \text { CAAR } & \text { Cumulative Average Abnormal Return } \\ \text { COVID-19 } & \text { Coronavirus Disease of 2019 } \\ \text { EC } & \text { Emergency Committee } \\ \text { LQ45 } & \text { 45 Companies with Highest Liquidity and Capitalization } \\ \text { PHEIC } & \text { Public Health Emergency of International Concern } \\ \text { SARS CoV-19 } & \text { Severe Acute Respiratory Syndrome Coronavirus } 2 \\ \text { WHO } & \text { World Health Organization } \\ \text { IDXENERGY } & \text { IDX Sector Energy } \\ \text { IDXINDUST } & \text { IDX Sector Industrials } \\ \text { IDXBASIC } & \text { IDX Sector Basic Materials } \\ \text { IDXINFRA } & \text { IDX Sector Infrastructures } \\ \text { IDXFINANCE } & \text { IDX Sector Financials } \\ \text { IDXHEALTH } & \text { IDX Sector Healthcare } \\ \text { IDXNONCYC } & \text { IDX Sector Consumer Non-Cyclicals }\end{array}$

\section{Introduction}

The distribution of a dividend has been a common corporate action in stock markets. A dividend is a ratio taken from a firm's profit that is available for distribution to the shareholders. Based on the type, dividends are classified into cash dividends and stock dividends. Moreover, based on the period of distribution and how the dividends are proposed, dividends are classified into interim dividends and final dividends. An interim dividend refers to the dividend distributed by the company before the annual report is issued. Gul et al. (2020) in their research stated that an interim dividend can be paid quarterly or semiannually. Meanwhile, a final dividend refers to the dividend which is distributed after the annual financial report (Gul et al. 2020; Sah 2015).

For the investors, earning dividends is an additional alternative to get a return from their investment other than the capital gain. In some cases, the dividend policy issued by the company may not be seen as a mere profit bearer but also as a source of information. According to a theory called Dividend Signaling Theory, a dividend becomes one of the ways to give a signal to the shareholders regarding the company's condition since there is asymmetric information between the management and the shareholders (Bhattacharya 1979). Ozo and Arun (2019) as well as Frensidy et al. (2019) have discovered a significant abnormal return around the dividend announcement date. Thus, the Dividend Signaling Theory is confirmed to still exist in the recent era. Asymmetric information refers to the condition where the shareholders do not have access to the company's policies that can influence its performance (Godager et al. 2019). In this situation, if the company announces a dividend, the shareholder will further analyze the dividend pattern whether it is dividend initiation, dividend omission, dividend increase or dividend decrease. Consequently, the shareholders might as well study the company's condition more thoroughly to make investment decisions. 
In early 2020, the global society encountered the outbreak of the novel coronavirus known as SARS-CoV-2 or COVID-19. The rapid spreading of the virus caused the outbreak to be declared as a Public Health Emergency of International Concern (PHEIC) by the Emergency Committee (EC) of the World Health Organization (WHO) at the end of January 2020 (World Health Organization 2020). The cautiousness of the society toward the viral infections of COVID-19 has caused a ripple effect to many aspects of the society, unexceptionally the economic aspect (Hossain 2020). In preventing the terrible impact of the outbreak, various policies have been applied by different countries in the world. The governments of every country affected have been kept busy examining the most suitable policy throughout the development of this COVID-19 outbreak. Yet, the negative impact experienced by the economy remains unavoidable (Ibn-Mohammed et al. 2020). Indonesia's newest update on Gross Domestic Product growth recorded a 3.49\% decline in the third quarter of 2020 compared to the same quarter from the previous year. The deepest fall was recorded in the second quarter as a $4.19 \%$ decline compared to the previous quarter (Badan Pusat Statistik 2020). Those facts characterized the period of 2020 as a sluggish economic period.

The economic slowdown, added with the issuance of several policies like the Large-Scale Social Restriction, has caused many people to experience layoffs or financial difficulties including the investors. This may affect the volatility of the capital market during the concerned period. Khanal and Mishra (2017) have examined the stock price magnitudes around the stock dividend announcement in the period of sluggish economic growth from 2006 to 2012. Their research has discovered that there is a significant increase in stock prices caused by the stock dividend announcements during that period. However, the limitation of their research is that they focused only on the stock dividend and neglected the cash dividend announcement. Abreu and Gulamhussen (2013), who investigated the US Bank Holding Companies before and during the crisis around 2007 until 2009, have spotted a difference in the expected growth's reaction toward the dividend payout. Before the financial crisis, the expected growth reacted insignificantly toward the dividend payout. Meanwhile, during the financial crisis, the expected growth reacted positively to the dividend payout. Those results imply that during a sluggish economic period, the Dividend Signaling Theory will most likely increase in its effectiveness.

An examination of the effect of COVID-19 period toward the stock market's volatility with a comparison to the normal situation can be used as a reference for future academic purposes. Thus, this research undertakes those issues. Based on the phenomenon discussed above, the following research questions are formulated.

RQ1: How is the abnormal return in \pm 10 (ten) days around the cash dividend announcement date of the companies listed in IDX before and during the COVID-19 Pandemic?

RQ2: How does the market reaction to dividend announcements before and during the COVID-19 pandemic differ from each other?

Referring to the previously discussed background theories, research problems, and research questions, the aim of this research is to comprehend the changes in the dividend announcement effect in Indonesia Stock Exchange when the COVID-19 pandemic, as a globally urgent situation, occurred. This research has at least 2 (two) 
contributions or significance. The first significance is that this research will complement former studies regarding the market reaction toward the dividend announcement in a sluggish economic condition. The second significance is that this research will discover the COVID-19 pandemic effects to the market's reaction toward dividend announcement in Indonesia to help the readers in understanding the situation and take the best decision to cope with similar condition.

Besides analyzing the dividend announcement effect before and during the pandemic, this research will also explain about the reaction toward the dividend increase and dividend decrease as well as the stock risks condition. Reaction toward the dividend increase and decrease as well as stock-risk profiling as a complementary explanation can help the readers to know the details of the changes happened in the dividend announcement effect for further consideration.

\section{Literature review and hypotheses development}

\section{Dividend signaling theory}

The dividend signaling theory suggests that there is asymmetric information between the firm management and the shareholders. Asymmetric information refers to the condition in which the shareholders are not aware of the information that can only be accessed by the firm's management (Meza et al. 2020). Such information as investments, project initiation, or merger and acquisition cannot be accessed directly by the investors. Therefore, the lack of access creates a gap of knowledge between the management and the shareholders. However, the corporate action taken will affect what the firm will do about its dividend policy. The theory implies that in the existence of asymmetric information, a change in dividend can signalize the company's current or future condition. Thus, considering the assumptions given, a particular market reaction around the dividend announcement date is expected. Consequently, as a signal, an analysis that only utilizes the dividend policy may not be accurate. Thus, the analysis to discover the company's condition after receiving a signal from the dividend should be combined with the analysis of other aspects to increase the prediction accuracy.

Many empirical studies have been conducted to prove the relevancy of the dividend signaling theory, and the results are diverse. Anwar et al. (2017), who tried to prove the dividend signaling theory, studied the Indian stock market and found out that significantly positive abnormal returns around the dividend announcement justifies the dividend signaling theory. In addition, Anwar et al. (2017) has proposed that the condition of a recession caused a decrease in the abnormal returns' significance. Evidence from the Saudi Arabia stock market also shows that there is a significantly positive relationship between the dividend announcement and the abnormal returns (Chaabouni 2017). On the other hand, Kadioglu et al. (2015), who have studied the Turkish stock market, has found out an opposite result. The Turkish stock market's abnormal returns responded to the dividend announcement with a significantly negative reaction. This result supports the tax-clientele effect theory proposed by Modigliani and Miller (1958). Fabian and Santoso (2020), who specify in the market 
reaction toward the dividend omission and dividend initiation of non-financial companies in the Indonesia stock market, has discovered a difference of reaction before and after the announcement period. Their research shows that before the dividend initiations announcement date, the average abnormal return is higher than after the announcement date and during the dividend omission period. Meanwhile, the average abnormal return before and after the announcement date shows no significant difference.

Other researches, like Mestel et al. (2003) have discovered that the dividend pattern relates positively with the stock price pattern, and Felimban et al. (2018), who has assessed the Gulf Cooperation Council (GCC) countries, has found that there is a delay in the market reaction toward the dividend increase. Felimban et al. (2018)'s research informs that since there is a low efficiency in the GCC market, a significant negative share price as a result of the dividend decrease, and when the dividend is constant, no significant effect is seen.

\section{Hypothesis formulation}

Khanal and Mishra (2017) have done research that investigated the reaction shown by the stock price toward the stock dividend announcement while taking the case of a sluggish economic period. The result exhibited that the market will most likely react in a significantly positive manner in the case of stock dividend announcement. Khanal and Mishra (2017) also stated that the fluctuation was less significant in the examined period of a sluggish economic situation than the previous studies conducted in a normal economic period. The findings of Khanal and Mishra (2017) are supported by Anwar et al. (2017) who has inspected the market reaction toward the cash dividend announcement in the Indian market. Anwar et al. (2017) confirms the Dividend Signaling Theory as well since they found out that the market reacts significantly positive toward the cash dividend announcement. Anwar et al. (2017) also extended their research to examine the pre-recession (2003-2008) stock market reaction and the post-recession (2009-2013) stock market reaction. Based on the examination, similar to Khanal and Mishra (2017), Anwar et al. (2017), a decrease in the abnormal return of the post-recession period compared to the pre-recession period has been discovered.

In addition, studies by Fabian and Santoso (2020), Felimban et al. (2018), and Mestel et al. (2003) classified the changes in cash dividend announcement into an increase in the dividend, a decrease in the dividend, and a constant dividend. Their studies have proven that the market may react differently in different dividend patterns. Therefore, accumulating the assumptions from the previous studies, the hypotheses for the cash dividend announcement are as follows:

H1 There is a difference between the market reaction to dividend announcement during the COVID-19 pandemic and before the pandemic.

Moreover, to answer the RQ3 formulated previously, the author takes into account Khanal and Mishra (2017) and Anwar et al. (2017)'s findings that the market reaction toward the dividend announcements is less significant during a recession compared to before the recession. Anwar et al. (2017) explained that the findings have 
supported the concept that the market tends to be pessimistic toward a dividend announcement during a recession period due to the lack of certainty in return. Thus, conceiving the bottom line from previous researches, a hypothesis is formulated as follows:

H2 There is abnormal return \pm 10 (ten) days around the cash dividend announcement of the sample companies.

\section{Research methods}

\section{Data}

As explained previously, the present research will associate abnormal return and dividend announcements; thus, there will be two types of data taken, which are dividend announcement documents and daily price fluctuation in related periods. Both data will be sourced from secondary documentary data. The dividend announcement documents were retrieved from Indonesia Central Securities Depository (www. ksei.co.id), while the daily fluctuation price was retrieved from the Indonesia Stock Exchange (www.idx.co.id). To prevent vagueness of the data, the researcher will use purposive sampling to exclude as much unneeded data as possible. Purposive sampling is suitable for this research since it enables the author to choose the desired criteria to sort out the sample on one's own (Sharma 2017). Written below are the predetermined sampling criteria for the dividend announcement data:

1. The selected companies are those that distributed dividends in both 2019 and 2020 .

2. The selected companies are those included in the LQ45 index. The LQ45 index is chosen because the stocks of the companies listed there are actively traded. Thus, analyzing the market reaction in active stocks will provide more accurate data.

3. The companies do not apply other corporate actions that may affect the abnormal return, such as stock split, reverse stock split, buyback, merger, acquisition, etc., around the studied period.

4. The samples that enable confounding effects, such as postponed dividend payout ratio and revised dividend payout ratio, are not included in the calculation.

Therefore, based on the predetermined sampling criteria, the available samples are as listed below (Table 1).

\section{Event study methodology}

The data in this research will be further analyzed using the event study methodology. It is one of the research tools used for finance and stock market analysis. The method aims to determine the effect of an event on the stock market volatility (Liu et al. 2018, 2020). Data testing using this method will require a rate of normal return that will be used as a benchmark for the daily stock returns (Fig. 1). 
Table 1 Sample companies. Source: Compiled by Author

\begin{tabular}{|c|c|c|c|c|c|}
\hline \multirow[t]{2}{*}{ Firm code } & \multirow[t]{2}{*}{ Company name } & \multirow[t]{2}{*}{ Dividend type } & \multicolumn{2}{|l|}{$\begin{array}{l}\text { Dividend } \\
\text { amount }\end{array}$} & \multirow[t]{2}{*}{ Dividend pattern } \\
\hline & & & 2019 & 2020 & \\
\hline ITMG & PT. Indo Tambangraya Megah Tbk & Final & 2045.00 & 570.00 & Decreased \\
\hline UNTR & PT. United Tractors Tbk & Final & 828.00 & 805.00 & Decreased \\
\hline ASII & PT. Astra International Tbk & Final & 154.13 & 157.00 & Increased \\
\hline ANTM & PT. Aneka Tambang Tbk & Final & 12.74 & 2.82 & Decreased \\
\hline WIKA & PT. Wijaya Karya (Persero) Tbk & Final & 56.99 & 50.96 & Decreased \\
\hline PTPP & PT. PP (Persero) Tbk & Final & 48.45 & 33.84 & Decreased \\
\hline AKRA & PT. AKR Corporindo Tbk & Final & 120.00 & 50.00 & Decreased \\
\hline JSMR & PT. Jasa Marga (Persero) Tbk & Final & 45.52 & 15.20 & Decreased \\
\hline HMSP & PT. Hanjaya Mandala Sampoerna Tbk & Final & 117.20 & 119.80 & Increased \\
\hline $\mathrm{BBNI}$ & $\begin{array}{l}\text { PT. Bank Negara Indonesia (Persero) } \\
\text { Tbk }\end{array}$ & Final & 201.29 & 206.24 & Increased \\
\hline BMRI & PT. Bank Mandiri (Persero) Tbk & Final & 241.22 & 353.34 & Increased \\
\hline BBTN & $\begin{array}{l}\text { PT. Bank Tabungan Negara (Persero) } \\
\text { Tbk }\end{array}$ & Final & 53.03 & 1.98 & Decreased \\
\hline UNVR & PT. Unilever Indonesia Tbk & Final & 775.00 & 107.00 & Decreased \\
\hline INTP & PT. Indocement Tunggal Prakarsa Tbk & Final & 550.00 & 500.00 & Decreased \\
\hline SMGR & PT. Semen Indonesia (Persero) Tbk & Final & 207.64 & 40.33 & Decreased \\
\hline KLBF & PT. Kalbe Farma Tbk & Final & 26.00 & 20.00 & Decreased \\
\hline CPIN & PT. Charoen Pokphand Indonesia Tbk & Final & 118.00 & 81.00 & Decreased \\
\hline TLKM & PT. Telekomunikasi Indonesia Tbk & Final & 163.82 & 154.07 & Decreased \\
\hline ICBP & $\begin{array}{l}\text { PT. Indofood CBP Sukses Makmur } \\
\text { Tbk }\end{array}$ & Final & 137.00 & 215.00 & Increased \\
\hline INDF & PT. Indofood Sukses Makmur Tbk & Final & 171.00 & 278.00 & Increased \\
\hline SRIL & PT. Sri Rejeki Isman Tbk & Final & 3.00 & 1.00 & Decreased \\
\hline TKIM & PT. Pabrik Kertas Tjiwi Kimia Tbk & Final & 50.00 & 25.00 & Decreased \\
\hline INKP & PT. Indah Kiat Pulp and Paper Tbk & Final & 100.00 & 50.00 & Decreased \\
\hline
\end{tabular}

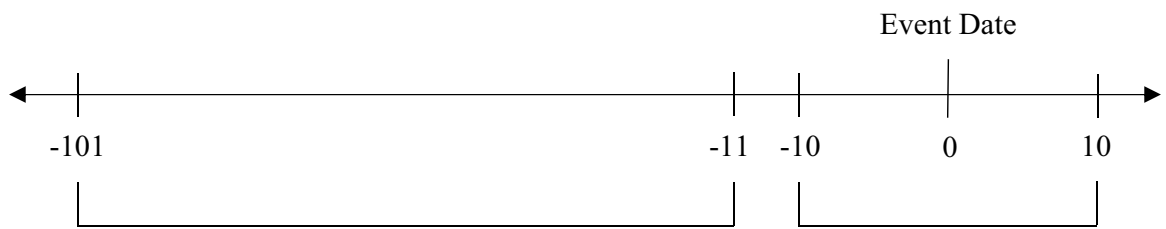

Estimation Window

Event Window

Fig. 1 Event Study Timeline (in days). Source: Compiled by Author

To find out the return rates, event study methodology involves two kinds of time periods, which are the estimation window and the event window. The estimation window is a period of study prior to the event window that is used to 
examine the normal returns of the market. In the present research, the estimation window will be taken 90 days before the event window. The general convention on deciding the estimation window is one year before the event window, or approximately 200-255 trading days prior to the event window. However, assuming that the stock market contains many uncertainties, specifying a period that is too long may reduce the accuracy rate. Thus, the author limits it to 90 days only. Meanwhile, the event window will be taken ten trading days before the dividend announcement, the dividend announcement day, and ten trading days after the dividend announcement of the corresponding company.

\section{Technique of analysis}

There is one independent variable and one dependent variable being modeled in the present research. Both variables will be analyzed using a daily basis analysis. The independent variable is the dividend announcement that will affect the dependent variable, which is the stock price.

1. The expected return will be calculated using the market model. The calculation will be based on Eq. 1 below:

$$
E R_{i, t}=\alpha_{i}+\beta_{i} R_{m, t}
$$

where $E R_{i, t}$ is each security's expected return at time $t, \alpha_{i}$ and $\beta_{i}$ is the estimated parameter of the security, $R_{m, t}$ is the return of the market at time $t$.

2. The actual return will be calculated using the Actual Return formula given as per Eq. 2:

$$
R_{i, t}=\frac{\left(P_{t}-P_{t-1}\right)}{P_{t-1}}
$$

where $R_{i, t}$ is the actual return.

3. After the results of the actual return and expected return are devised, the analysis will be continued by computing the abnormal return. Several researchers conducting studies with similar topics also utilized the abnormal return analysis to decide on the market reaction (Anwar et al. 2017; Chaabouni 2017; Fabian and Santoso 2020; Kadioglu et al. 2015; Khanal and Mishra 2017). The abnormal return can be obtained from the difference between the expected return and the actual return. Thus, the abnormal return per day $\left(A R_{i, t}\right)$ will be computed using the formula as in Eq. 3:

$$
A R_{i, t}=R_{i, t}-E R_{i, t}
$$

4. Furthermore, the abnormal returns will be accumulated into AAR (Average Abnormal Return). Assuming $N$ is the number of companies, the detailed calculation is as in Eq. 4: 


$$
A A R=1 / N \sum_{i=1}^{N} A R_{i, t}
$$

5. Ensuring the relationship between variables in the studied event window begins in $t$ and ends in $k$, the AAR will be summed into CAAR (Cumulative Average Abnormal Return). The formula is as in Eq. 5:

$$
C A A R_{i}(t, k)=\sum_{t=-10}^{k} A A R_{t}
$$

6. The variance of the sample is calculated as:

$$
S_{A A R}^{2}=\frac{1}{89} \sum_{T=-101}^{-11}\left(A A R_{t}-\overline{A A R}_{t}\right)^{2}
$$

while the standard deviation is the square root of variance.

7. Then, the $t$ statistics that are going to be used to test the hypothesis will be computed using the following equation:

$$
t \text { Statistic }=\frac{\overline{A A R}_{\text {after }}-\overline{A A R}_{\text {before }}}{\left(\frac{\sigma_{\text {after }}}{n}+\frac{\sigma_{\text {before }}}{n}\right)}
$$

where the difference of AAR before and after the dividend announcement date is divided by the sum of standard deviation with respect to the number of days accordingly.

Lastly, the results of the hypothesis test are going to be further summarized and interpreted.

\section{Results and discussion}

\section{Abnormal returns before and during the COVID-19 pandemic}

Using the event study methodology, the abnormal returns of the sample companies during the event window was calculated. The results were then combined as the average abnormal returns that represent the whole sample. The summarized average abnormal returns of the sample companies during the event window period in both 2019 and 2020 are shown in Table 2. In order to perform a significance test, this research uses the one sample $t$-test on the average abnormal returns. The $t$ statistics of the average abnormal returns were being analyzed under the significance level of $0.01,0.05$, and 0.1 as shown in Table 2 .

A general overview of the abnormal return comparison between the year 2019 and 2020 has been done. A one sample paired $t$-test was used to analyze the average abnormal returns for both years. For each year, the difference between the 
Table 2 AAR, CAAR, and $t$ Statistics of the sample companies in 2019 and 2020. Source: Compiled by Author

\begin{tabular}{|c|c|c|c|c|c|c|c|c|}
\hline \multirow{2}{*}{$\begin{array}{l}\text { Time- } \\
\text { line }\end{array}$} & \multicolumn{2}{|l|}{ AAR } & \multicolumn{2}{|c|}{$t$ Statistics per day } & \multicolumn{2}{|l|}{ CAAR } & \multicolumn{2}{|c|}{$t$ Statistics per day } \\
\hline & 2019 & 2020 & 2019 & 2020 & 2019 & 2020 & 2019 & 2020 \\
\hline$t+10$ & -0.07878 & -0.36864 & $-0.10235^{* *}$ & -3.23606 & -1.81195 & -7.28332 & -2.35400 & $-63.93601^{*}$ \\
\hline$t+9$ & -0.09372 & -0.3588 & $-0.12119^{* * *}$ & -3.22643 & -1.73317 & -6.91468 & -2.24100 & $-62.17848 *$ \\
\hline$t+8$ & -0.09608 & -0.34749 & $-0.12380^{* * *}$ & -2.71029 & -1.63944 & -6.55588 & -2.11250 & $-51.13339 *$ \\
\hline$t+7$ & -0.08989 & -0.34669 & $-0.11644^{* * *}$ & -2.85618 & -1.54337 & -6.20839 & -1.99921 & $-51.14800 *$ \\
\hline$t+6$ & -0.08335 & -0.34228 & $-0.10685^{* *}$ & -2.82019 & -1.45348 & -5.86170 & -1.86313 & $-48.29681^{*}$ \\
\hline$t+5$ & -0.08324 & -0.34966 & $-0.10809^{* *}$ & -2.98162 & -1.37012 & -5.51942 & -1.77915 & $-47.06488^{*}$ \\
\hline$t+4$ & -0.09546 & -0.34933 & $-0.12541 * * *$ & -2.99469 & -1.28688 & -5.16976 & -1.69063 & -44.31820 \\
\hline$t+3$ & -0.08734 & -0.34925 & $-0.11387^{* *}$ & -3.02055 & -1.19142 & -4.82043 & -1.55337 & $-41.69004 *$ \\
\hline$t+2$ & -0.08342 & -0.34394 & $-0.11024^{* *}$ & -3.16522 & -1.10408 & -4.47117 & -1.45907 & $-41.14748 *$ \\
\hline$t+1$ & -0.08409 & -0.34899 & $-0.10845^{* *}$ & -2.92799 & -1.02066 & -4.12723 & -1.31631 & $-34.62675^{*}$ \\
\hline$t$ & -0.07898 & -0.35378 & $-0.10127^{* *}$ & -3.01211 & -0.93658 & -3.77824 & -1.20087 & -32 \\
\hline$t-1$ & -0.08577 & -0.3496 & $-0.11078^{* *}$ & -2.95003 & -0.85759 & -3.42446 & -1.10763 & -28 \\
\hline$t-2$ & -0.08888 & -0.3455 & $-0.11441^{* * *}$ & -2.79601 & -0.77182 & -3.07486 & -0.99358 & $-24.88393^{*}$ \\
\hline$t-3$ & -0.07883 & -0.33951 & $-0.10226^{* *}$ & -2.78676 & -0.68295 & -2.72936 & -0.88598 & $-22.40315^{*}$ \\
\hline$t-4$ & -0.08172 & -0.34866 & $-0.10555^{* *}$ & -2.88696 & -0.60412 & -2.38985 & $-0.78025^{* * *}$ & $-19.78862 *$ \\
\hline$t-5$ & -0.09266 & -0.33854 & $-0.11984 * * *$ & -2.87707 & -0.52240 & -2.04120 & $-0.67563^{* * *}$ & $-17.34689^{*}$ \\
\hline$t-6$ & -0.09076 & -0.34077 & $-0.11623^{* * *}$ & -2.94190 & -0.42974 & -1.70265 & $-0.55035^{* * *}$ & $-14.69906^{*}$ \\
\hline$t-7$ & -0.09354 & -0.34443 & $-0.12120 * * *$ & -2.94790 & -0.33898 & -1.36188 & $-0.43922 * * *$ & $-11.65617^{*}$ \\
\hline$t-8$ & -0.06518 & -0.33114 & $-0.08319 * *$ & -2.66852 & -0.24544 & -1.01745 & $-0.31325^{* * *}$ & $-8.19934 *$ \\
\hline$t-9$ & -0.08231 & -0.34901 & $-0.10727^{* *}$ & -2.96955 & -0.18026 & -0.68632 & $-0.23492 * * *$ & $-5.83953^{*}$ \\
\hline$t-10$ & -0.09795 & -0.33731 & $-0.12468 * * *$ & -2.57549 & -0.09795 & -0.33731 & $-0.12468 * * *$ & -2.57549 \\
\hline
\end{tabular}

*Significant at 0.1 level, **significant at 0.05 level, ***significant at 0.01 level

pre-announcement and post-announcement average was calculated with respect to each standard deviation in order to find the $t$ statistics. The calculation has discovered the $t$ statistics of 2019 and 2020 for respectively 136.56977 and 564.55602. The numbers are greater than the $t$ table in all the significance levels of $0.01,0.05$, and 0.1 . This implies that, under the one sample $t$-test, the results have rejected the null 
hypothesis and accepted H1 in a significant manner. Therefore, there is a great difference between the abnormal returns around the dividend announcement before and during the COVID-19 pandemic.

On a daily basis, the $t$ statistics were being examined as well. From the event window in 2019, the $t$ statistic numbers are negative. The range is from -0.083188 on the eighth day before the event $(t-8)$ as the lowest value and -0.125405 on the fourth day after the event $(t+4)$ as the highest value. The spread exceeds the $t$ table value under the significance level of either $0.01(-2.81876), 0.05(-2.07387)$, or $0.1(-1.71714)$, which confirms that the null hypothesis has been accepted. The acceptance indicates that in the event window of 2019, abnormal returns were not found. Although there is a significant difference between the dividend announcement effect before and during the pandemic, the dividend announcement itself does not give a critical impact on the stock prices. It is shown by the insignificant changes in abnormal return around the dividend announcement date.

The result obtained is not aligned with the study from Frensidy et al. (2019) who has analyzed the dividend effect in Indonesia Stock Exchange from 2007 to 2012 and discovered a significant abnormal return around the dividend announcement date. Frensidy et al. (2019) has also mentioned that significant abnormal returns indicate an active response from the market to gain returns from the event. Thus, it confirms that the stock market manifests weak and delayed response toward the event. Pratama et al. (2020) who have examined the stock market reaction in the period of 2019 toward presidential election and Putra and Badjra (2021) with their research in the market reaction toward 2019's stock split announcement, have discovered similar results where no abnormal returns are found.

Meanwhile, the $t$ statistic values in 2020 exhibit mixed results. Under the significance level of 0.05 and 0.1 , the $t$ statistics that are ranged from -3.236065 to -2.575491 have rejected the null hypothesis, therefore, abnormal returns are found. Meanwhile, the $t$-test results for the significance level of 0.01 , varies. On the ninthday pre-event $(t-9)$, seventh to fourth day pre-event $(t-7$ to $t-4)$, one day preevent to seventh day post-event $(t-1$ to $t+7)$, and ninth to tenth day post-event $(t+9$ to $t+10)$, the $t$ statistics are less than the $t$ table, therefore rejecting the null hypothesis, hence, indicates that there is abnormal return happening in those days. However, on the tenth day pre-event $(t-10)$, eighth day pre-event $(t-8)$, third to second day pre-event $(t-3$ to $t-2)$, and eighth day post-event $(t+8)$, the null hypothesis is accepted, thus, there were no abnormal returns found. In summary, the overall results are dominated by negative insignificant abnormal returns in which the values are much lower than the returns in 2019. Therefore, Indonesian Stock Exchange provides a sluggish response toward the event. This result is in line with the research by Mujib and Candraningrat (2021) and Frensidy et al. (2019) who have also found insignificant negative abnormal returns toward the COVID-19 pandemic, as well as Anwar et al. (2017) who discovered that during a recession period of 2003-2013, the returns of the stock decreased significantly compared to the normal condition.

The decrease in the stock market returns in 2020 is caused mainly by the emergence of COVID-19 pandemic. As stated by Schell et al. (2020), COVID-19 causes the most severe effect to the global stock market compared to the other disease 
outbreaks, such as Swine Influenza, Polio, Ebola and Zika. The impact of the COVID-19 pandemic becomes significant due to the crucial policies like the LargeScale Social Restrictions that weighted the economy, causing it to grow sluggishly and leads to a bearish market pattern due to the less active market in reacting to other sentiments (Khanal and Mishra 2017). The illustration of the difference in the average abnormal returns and cumulative abnormal returns between 2019 and 2020 can be seen, respectively in Figs. 2 and 3.

Furthermore, the highest average abnormal return of 2019's event window happened on the eighth day prior to the dividend announcement date $(t-8)$ and the lowest average abnormal return in 2019 happened on the tenth day prior to the dividend announcement date $(t-10)$. Meanwhile, in 2020, the highest average abnormal return happened on the eighth day prior to the dividend announcement date $(t-8)$ and the lowest average abnormal return happened on the tenth day after the dividend announcement $(t+10)$. A pattern where the highest average abnormal return happened in the eighth day pre-event $(t-8)$ in both 2019 and 2020, can indicate that there was a leakage of information prior to the issuance of the dividend announcements (Chaabouni 2017). However, it does not rule out the possibility that it was a mere coincidence. Longer period of analysis should be taken to prove it.

In line with the AAR, the CAAR for both 2019 and 2020 formed a consistent downline. The patterns indicate that the market has been consistently pessimistic toward the dividend announcement in either before or during the COVID-19 pandemic. The $t$ statistics of CAAR in 2019 are significantly negative starting from the tenth day pre-event $(t-10)$ to fourth day pre-event $(t-4)$ under the significance level of 0.01 and constantly insignificant in the following days. Meanwhile, the $t$ statistics of CAAR in 2020 have been significant starting from the ninth-day pre-event

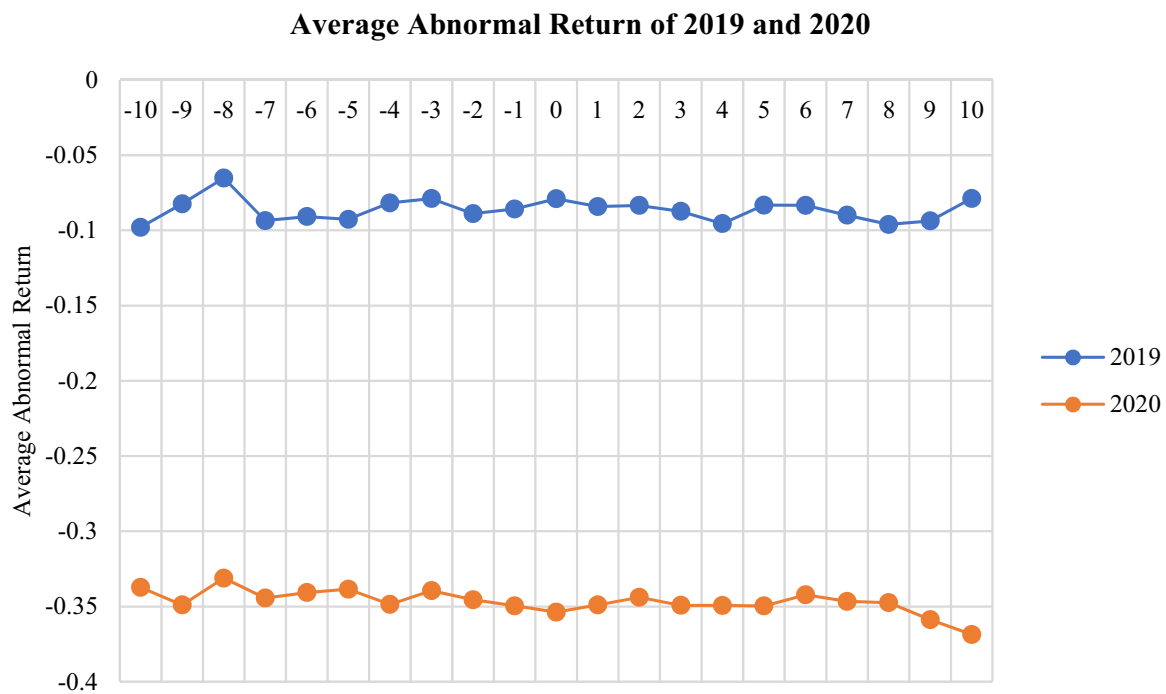

Fig. 2 Average Abnormal Returns of the sample companies in 2019 and 2020. Source: Compiled by author 


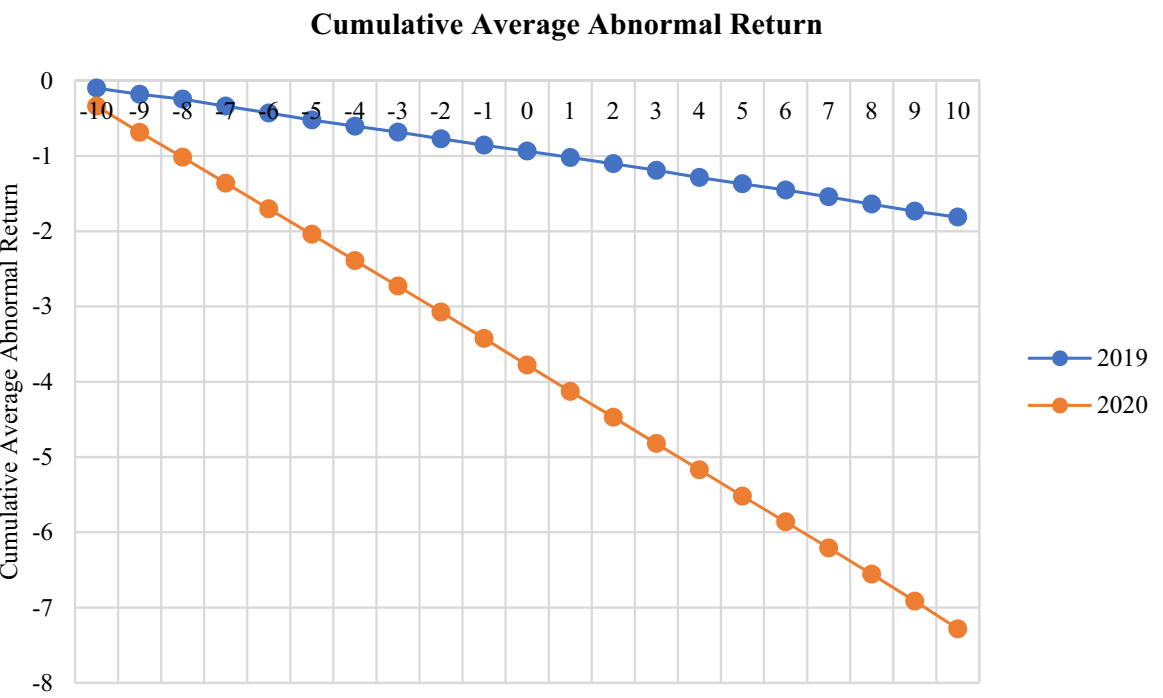

Fig. 3 Cumulative Average Abnormal Returns of the sample companies in 2019 and 2020. Source: Compiled by author

until the end of the event window under the significance level of either 0.01, 0.05, or 0.1. Looking at the steepness of the 2020's downline shown in Fig. 3, it can be implied that the market response during the existence of the COVID-19 pandemic has been more pessimistic compared to the response from 2019.

\section{Dividend increase and dividend decrease}

Among the 23 sample companies that have been taken, there are 17 companies that distributed less amount of dividend in 2020 compared to 2019. On the contrary, 6 companies recorded an increase in dividend. Based on the AAR as shown in Table 3 as well as illustrated in Figs. 4 and 5, the market reaction difference toward the dividend decrease and dividend increase can be seen.

From the AAR values, it can be implied that the market reacts differently toward the dividend announcement of the companies with decreased dividend and toward the dividend announcement of the companies with increased dividend. Before the emergence of the COVID-19 pandemic, the companies with increased dividend received a positive AAR which indicates that the investors are optimistic in the information provided by the announcement. However, after the pandemic hit, the market provided a negative response upon the good news. Meanwhile, in case of the dividend decrease, negative reactions are found in both 2019 and 2020. The negative reaction exhibited by the market indicates that the investors have anticipated the unfavorable news and adds it to their cautiousness of spending their investment funds. 
Table 3 AAR summary of the companies with decreased dividend and increased dividend. Source: Compiled by Author

\begin{tabular}{|c|c|c|c|c|c|c|c|c|c|}
\hline \multirow[t]{2}{*}{ Timeline } & \multicolumn{2}{|c|}{ Decreased dividend } & \multicolumn{2}{|c|}{ Increased dividend } & \multirow[t]{2}{*}{ Timeline } & \multicolumn{2}{|c|}{ Decreased dividend } & \multicolumn{2}{|c|}{ Increased dividend } \\
\hline & 2019 & 2020 & 2019 & 2020 & & 2019 & 2020 & 2019 & 2020 \\
\hline$t+10$ & -0.20768 & -0.36649 & 0.28643 & -0.37473 & $t-1$ & -0.22214 & -0.35360 & 0.30061 & -0.33828 \\
\hline$t+9$ & -0.22845 & -0.35776 & 0.28798 & -0.36175 & $t-2$ & -0.22459 & -0.34819 & 0.29564 & -0.33787 \\
\hline$t+8$ & -0.23028 & -0.34581 & 0.28417 & -0.35224 & $t-3$ & -0.21395 & -0.34482 & 0.30403 & -0.32446 \\
\hline$t+7$ & -0.23231 & -0.35113 & 0.31363 & -0.33408 & $t-4$ & -0.21322 & -0.34920 & 0.29085 & -0.34712 \\
\hline$t+6$ & -0.22133 & -0.34262 & 0.30758 & -0.34132 & $t-5$ & -0.22241 & -0.33445 & 0.27497 & -0.35014 \\
\hline$t+5$ & -0.21948 & -0.34911 & 0.30276 & -0.35123 & $t-6$ & -0.23131 & -0.33876 & 0.30746 & -0.34646 \\
\hline$t+4$ & -0.23144 & -0.35226 & 0.28983 & -0.34104 & $t-7$ & -0.21644 & -0.34496 & 0.25469 & -0.34292 \\
\hline$t+3$ & -0.22364 & -0.34768 & 0.29885 & -0.35371 & $t-8$ & -0.19358 & -0.33245 & 0.29862 & -0.32741 \\
\hline$t+2$ & -0.21366 & -0.34611 & 0.28560 & -0.33777 & $t-9$ & -0.21874 & -0.35008 & 0.30423 & -0.34598 \\
\hline $\mathrm{t}+1$ & -0.22251 & -0.34604 & 0.30810 & -0.35737 & $t-10$ & -0.23580 & -0.33157 & 0.29263 & -0.35358 \\
\hline$t$ & -0.21558 & -0.34929 & 0.30805 & -0.36648 & & & & & \\
\hline
\end{tabular}

AAR of the Companies with Decreased Dividend

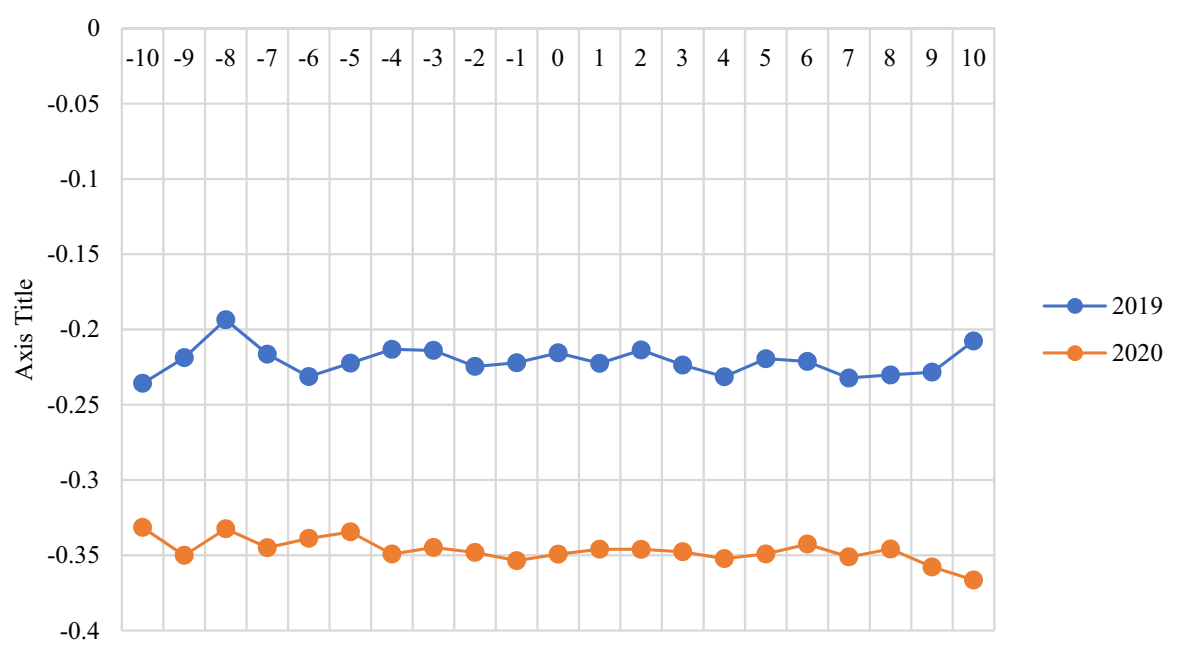

Fig. 4 Average Abnormal Return of the companies with decreased dividend. Source: Compiled by author

In summary, within a normal situation, increased dividend can be a good signal for the investors, since the market may react positively to the sentiment. However, in a highly uncertain situation, the COVID-19 pandemic for instance, the positive sentiment may not trigger significant reaction from the market. The COVID-19 pandemic causes very high uncertainty due to the multiple interconnected problems that occurred, such as the healthcare problem, credit issues, economic activity and productivity problems, etc. (Herwany et al. 2021). Those problems may distract the market from responding to the stock market sentiment. The pessimistic market 


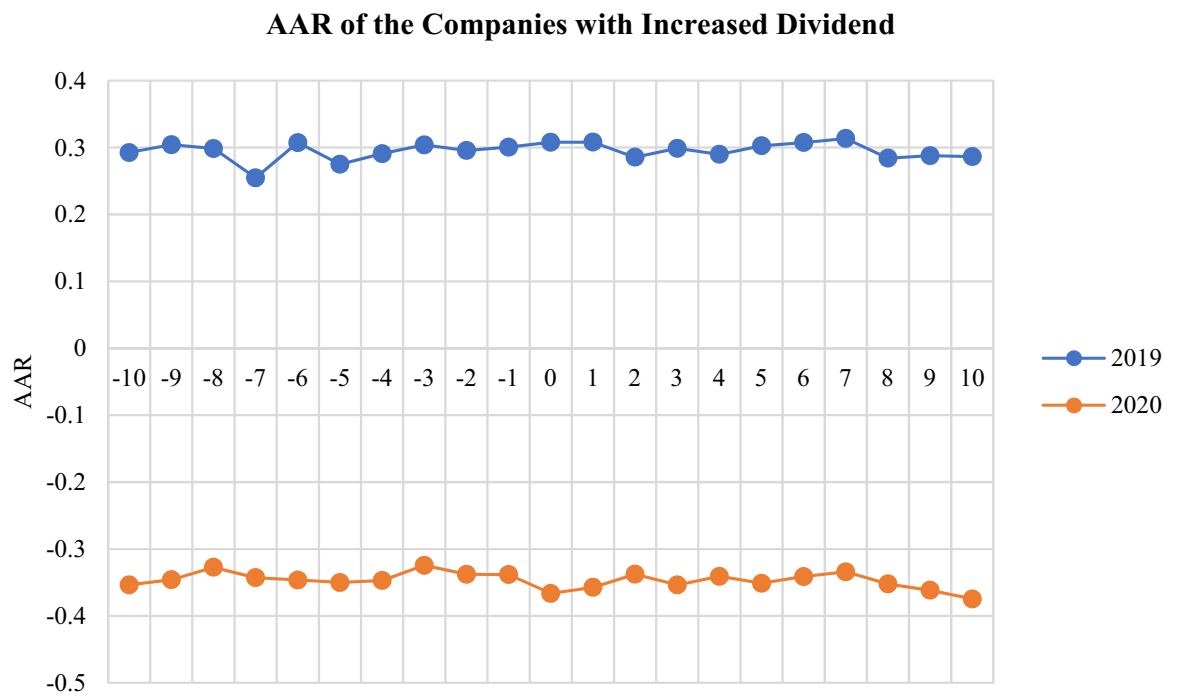

Fig. 5 Average Abnormal Return of the companies with increased dividend. Source: Compiled by author

reactions during the pandemic can be caused by the distraction as well. Nevertheless, further research should be done to confirm the real causes.

\section{Stocks return risk-profiling}

In order to analyze the stock performance risk-profiling, a calculation of standard deviation, mean, and coefficient of variation had been done. The calculation had been done separately between 10 days prior to the dividend announcement and 10 days after the dividend announcement. The average for each period is used to determine whether the company is categorized as high risk or low risk. In 2019, UNTR, HMSP, SMGR, TKIM, and INKP are categorized as high risk in both 10 days prior to the dividend announcement and 10 days after the dividend announcement. BBTN, UNVR, CPIN, and SRIL are categorized as low risk before the announcement and high risk after the announcement and the rest of the samples are categorized as low risk in both periods. On the other hand, in 2020, BBTN and INDF are both categorized as high risk in 10 days prior to the dividend announcement and 10 days after the dividend announcement. AKRA recorded a unique profile where it is categorized as high risk before the announcement and low risk after the announcement while the rest of the samples are categorized as low risk in both periods (Table 4).

Given the data, it can be concluded that the risk occurrence around the dividend announcement in the period of COVID-19 tends to be lower than the normal condition. The possible cause is due to the weaker market reaction toward the event. The investors are possibly being more cautious in making their investment decisions since the market manifests a lot of uncertainty, therefore causing a delay or even 
Table 4 Average Abnormal Return summary of the sample companies in 2019 and 2020. Source: Compiled by author

\begin{tabular}{|c|c|c|c|c|c|c|c|}
\hline \multirow[t]{2}{*}{ Firm code } & \multirow[t]{2}{*}{ Period } & \multicolumn{2}{|c|}{ Standard deviation } & \multicolumn{2}{|l|}{ Mean } & \multicolumn{2}{|c|}{$\begin{array}{l}\text { Coefficient of vari- } \\
\text { ations }\end{array}$} \\
\hline & & 2019 & 2020 & 2019 & 2020 & $2019(\%)$ & $2020(\%)$ \\
\hline \multirow[t]{2}{*}{ ITMG } & $(+1,+10)$ & 0.024078 & 0.034351 & -0.15764 & -0.39699 & 15.27 & 8.65 \\
\hline & $(-1,-10)$ & 0.015003 & 0.026621 & -0.13733 & -0.3921 & 10.92 & 6.79 \\
\hline \multirow[t]{2}{*}{ UNTR } & $(+1,+10)$ & 0.031414 & 0.023448 & -0.07499 & -0.39057 & 41.89 & 6.00 \\
\hline & $(-1,-10)$ & 0.024088 & 0.030451 & -0.07613 & -0.38995 & 31.64 & 7.81 \\
\hline \multirow[t]{2}{*}{ ASII } & $(+1,+10)$ & 0.025225 & 0.016676 & -0.17954 & -0.46338 & 14.05 & 3.60 \\
\hline & $(-1,-10)$ & 0.03102 & 0.031351 & -0.18073 & -0.45802 & 17.16 & 6.84 \\
\hline \multirow[t]{2}{*}{ ANTM } & $(+1,+10)$ & 0.026809 & 0.03241 & -0.37697 & -0.41698 & 7.11 & 7.77 \\
\hline & $(-1,-10)$ & 0.032088 & 0.032447 & -0.36707 & -0.41261 & 8.74 & 7.86 \\
\hline \multirow[t]{2}{*}{ WIKA } & $(+1,+10)$ & 0.034134 & 0.039402 & -0.68815 & -0.31499 & 4.96 & 12.51 \\
\hline & $(-1,-10)$ & 0.039863 & 0.025593 & -0.68787 & -0.27179 & 5.80 & 9.42 \\
\hline \multirow[t]{2}{*}{ PTPP } & $(+1,+10)$ & 0.037662 & 0.038563 & -0.32006 & -0.32342 & 11.77 & 11.92 \\
\hline & $(-1,-10)$ & 0.037329 & 0.026199 & -0.32111 & -0.28091 & 11.63 & 9.33 \\
\hline \multirow[t]{2}{*}{ AKRA } & $(+1,+10)$ & 0.016321 & 0.028866 & -0.22393 & -0.32221 & 7.29 & 8.96 \\
\hline & $(-1,-10)$ & 0.033014 & 0.073378 & -0.24827 & -0.29715 & 13.30 & 24.69 \\
\hline \multirow[t]{2}{*}{ JSMR } & $(+1,+10)$ & 0.028764 & 0.029393 & -0.85104 & -0.33105 & 3.38 & 8.88 \\
\hline & $(-1,-10)$ & 0.031673 & 0.04644 & -0.8598 & -0.34482 & 3.68 & 13.47 \\
\hline \multirow[t]{2}{*}{ HMSP } & $(+1,+10)$ & 0.012689 & 0.031353 & 0.056358 & -0.44946 & 22.52 & 6.98 \\
\hline & $(-1,-10)$ & 0.041553 & 0.027065 & 0.057579 & -0.43968 & 72.17 & 6.16 \\
\hline \multirow[t]{2}{*}{$\mathrm{BBNI}$} & $(+1,+10)$ & 0,028864 & 0.039462 & -0.86865 & -0.32166 & 3.32 & 12.27 \\
\hline & $(-1,-10)$ & 0.023413 & 0.012422 & -0.89091 & -0.29069 & 2.63 & 4.27 \\
\hline \multirow[t]{2}{*}{ BMRI } & $(+1,+10)$ & 0.047254 & 0.044914 & -0.27093 & -0.3162 & 17.44 & 14.20 \\
\hline & $(-1,-10)$ & 0.0148 & 0.007628 & -0.27213 & -0.30309 & 5.44 & 2.52 \\
\hline \multirow[t]{2}{*}{ BBTN } & $(+1,+10)$ & 0.03681 & 0.052158 & -0.15911 & -0.25059 & 23.13 & 20.81 \\
\hline & $(-1,-10)$ & 0.025534 & 0.060367 & -0.15469 & -0.26302 & 16.51 & 22.95 \\
\hline \multirow[t]{2}{*}{ UNVR } & $(+1,+10)$ & 0.038416 & 0.012104 & -0.20555 & -0.46122 & 18.69 & 2.62 \\
\hline & $(-1,-10)$ & 0.019565 & 0.007498 & -0.20407 & -0.4607 & 9.59 & 1.63 \\
\hline \multirow[t]{2}{*}{ INTP } & $(+1,+10)$ & 0.044926 & 0.017225 & -0.43531 & -0.32849 & 10.32 & 5.24 \\
\hline & $(-1,-10)$ & 0.029836 & 0.013708 & -0.44447 & -0.32335 & 6.71 & 4.24 \\
\hline \multirow[t]{2}{*}{ SMGR } & $(+1,+10)$ & 0.040043 & 0.013821 & -0.120001 & -0.30812 & 33.37 & 4.49 \\
\hline & $(-1,-10)$ & 0.037119 & 0.020271 & -0.116201 & -0.31001 & 31.94 & 6.54 \\
\hline \multirow[t]{2}{*}{ KLBF } & $(+1,+10)$ & 0.034413 & 0.018606 & -0.18972 & -0.35877 & 18.14 & 5.19 \\
\hline & $(-1,-10)$ & 0.029123 & 0.013298 & -0.18835 & -0.36469 & 15.46 & 3.65 \\
\hline \multirow[t]{2}{*}{ CPIN } & $(+1,+10)$ & 0.037885 & 0.025334 & 0.186559 & -0.32217 & 20.31 & 7.86 \\
\hline & $(-1,-10)$ & 0.037441 & 0.013418 & 0.187315 & -0.31522 & 19.99 & 4.26 \\
\hline \multirow[t]{2}{*}{ TLKM } & $(+1,+10)$ & 0.037885 & 0.015947 & -0.37791 & -0.54636 & 10.02 & 2.92 \\
\hline & $(-1,-10)$ & 0.023403 & 0.020192 & -0.37088 & -0.55065 & 6.31 & 3.67 \\
\hline \multirow[t]{2}{*}{ ICBP } & $(+1,+10)$ & 0.015301 & 0.008471 & -0.16289 & -0.55905 & 9.39 & 1.52 \\
\hline & $(-1,-10)$ & 0.031129 & 0.011557 & -0.17918 & -0.56134 & 17.37 & 2.06 \\
\hline INDF & $(+1,+10)$ & 0.035601 & 0.008473 & 3.204619 & 0.006596 & 1.11 & 128.46 \\
\hline
\end{tabular}


Table 4 (continued)

\begin{tabular}{|c|c|c|c|c|c|c|c|}
\hline \multirow[t]{2}{*}{ Firm code } & \multirow[t]{2}{*}{ Period } & \multicolumn{2}{|c|}{ Standard deviation } & \multicolumn{2}{|l|}{ Mean } & \multicolumn{2}{|c|}{$\begin{array}{l}\text { Coefficient of vari- } \\
\text { ations }\end{array}$} \\
\hline & & 2019 & 2020 & 2019 & 2020 & $2019(\%)$ & $2020(\%)$ \\
\hline & $(-1,-10)$ & 0.018611 & 0.011555 & 3.219627 & 0.004287 & 0.58 & 269.53 \\
\hline \multirow[t]{2}{*}{ SRIL } & $(+1,+10)$ & 0.010285 & 0.01765 & -0.02967 & -0.35887 & 34.66 & 4.92 \\
\hline & $(-1,-10)$ & 0.005741 & 0.018037 & -0.03089 & -0.36035 & 18.59 & 5.01 \\
\hline \multirow[t]{2}{*}{ TKIM } & $(+1,+10)$ & 0.031966 & 0.027698 & 0.0437 & -0.23838 & 73.15 & 11.62 \\
\hline & $(-1,-10)$ & 0.083087 & 0.028332 & 0.066606 & -0.22384 & 124.74 & 12.66 \\
\hline \multirow[t]{2}{*}{ INKP } & $(+1,+10)$ & 0.038071 & 0.039586 & 0.187498 & -0.28935 & 20.30 & 13.68 \\
\hline & $(-1,-10)$ & 0.115937 & 0.046404 & 0.226492 & -0.26658 & 51.19 & 17.41 \\
\hline \multirow[t]{2}{*}{ Average } & & $(+1,+10)$ & & & & 18.33 & 13.52 \\
\hline & & $(-1,-10)$ & & & & 21.83 & 19.68 \\
\hline
\end{tabular}

no reaction to the positive event. These findings are consistent with the research of Angelovska (2017) that has discovered that the investors in Macedonian stock market did not show any reaction toward the dividend policy during the recession period in 2008-2009.

Because of the emergence of the pandemic, various changes in risk have happened. INDF is one of the sample companies that has recorded a major change in the risk between the period before and during the COVID-19 pandemic. The risk recorded before the pandemic is within the range of $0-2 \%$, while after the pandemic, the range has increased to $100-300 \%$. However, it is contradictory with ICBP from the same sector of IDX Sector Consumer Non-Cyclical (IDXNONCYC). The risk average of ICBP in 2020 is the lowest from all of the sample companies with the number of $1.79 \%$. Therefore, due to the uncertainty, investors should be careful in building their portfolio to avoid unwanted situations. From all of the sample companies being analyzed, the companies with low risk in both 2019 and 2020, based on the sectors are ITMG (IDXENERGY), ASII (IDXINDUST), ANTM and INTP (IDXBASIC), WIKA, PTPP, JSMR, and TLKM (IDXINFRA), BBNI and BMRI (IDXFINANCE), KLBF (IDXHEALTH) and ICBP (IDXNONCYC). IDXINFRA is dominating with four low-risk companies on the list and may be suitable for the investors that are tend to be risk averse. However, further analysis still needs to be applied.

\section{Conclusion}

This research aimed to understand the changes in the stock market return toward dividend announcement in Indonesia Stock Exchange before the COVID-19 pandemic compared to during the COVID-19 pandemic. Twenty-three sample companies from the LQ45 index were taken and showed evidence that there is a difference between the market reaction before and during the COVID-19 pandemic. The AAR before the pandemic suggested that there is no significant reaction from 
the market toward the event causing the abnormal return to be non-existent. On the other hand, during the pandemic, negative abnormal returns were found in a relatively insignificant manner. In summary, both results bring up the conclusion that the market has provided a faint response to the event. Although, in the period of COVID-19 pandemic, the market has been more pessimistic compared to before the pandemic occurred.

In order to distinguish the dividend announcement effect of the companies with decreased dividend and companies with increased dividend, an assessment toward each AAR was taken. The results suggest that in 2019, the companies with decreased dividends got a negative reaction and the companies with increased dividends got a positive reaction. Meanwhile, in 2020, both dividend decrease and dividend increase got negative reactions. The difference between both periods supports an argument that during the disaster, the market becomes more pessimistic compared to the normal condition.

According to the risk profiling in 2019, 21.74\% sample companies are considered as high-risk companies in either 10 days pre- or post-announcement, $17.39 \%$ presented a low risk before the announcement and grew into high-risk companies after the announcement, and $60.87 \%$ appeared to be low-risk in both periods. The period of 2020 showed a different result. There are $8.69 \%$ sample companies recorded as high-risk companies, $4.35 \%$ showed a high risk before the announcement and low risk after the announcement, and $86.96 \%$ sample companies have low risk in both periods. The period of COVID-19 pandemic manifested a weaker response toward the event since the proportion of the companies with low volatility is higher than before the pandemic.

Considering the major changes of risk and return of the stocks when the COVID19 pandemic occurred. The investors should be cautious in building their investment portfolio in order to avoid unwanted consequences. Detailed analysis and investment strategy can be applied to take the investment decisions. On the other hand, from the evidence found in this research, the dividend announcement effect is proven to be ineffective for triggering certain market reactions. Therefore, especially in a sluggish situation similar to the COVID-19 pandemic, it is better for the companies to focus on improving and maintaining the business.

Objectively, this research has several fixable limitations. Those limitations include, first, the need of a longer period of analysis, especially the period that will be used for the parametric benchmark. This research uses only 2019 as the year for the parametric benchmark data; however, if the data of 2019 have been affected by another major exogenous factor, the results may become biased. Second limitation is the need of a wider sample companies. Having greater sample companies enables the author to provide a more detailed analysis and implications. Lastly, the third limitation is the need of another variable to include, such as trading volume activity or bid-ask spread. Other variables aside from stock prices can complement the analysis and provide a more compact explanation.

Author contributions All the authors have made an equal contribution to this study. 
Funding This research received no specific grant from any funding agency in the public, commercial, or not-for-profit sectors.

Availability of data and materials The datasets used and/or analyzed during the current study are available from the corresponding author on reasonable request.

\section{Declarations}

Conflict of interest The authors declare that they have no competing interests.

Ethics approval and consent to participate Not applicable.

Consent for publication Not applicable.

\section{References}

Abreu JF, Gulamhussen MA (2013) Dividend payouts: evidence from U.S. bank holding companies in the context of the financial crisis. J Corporate Finance 22(1):54-65. https://doi.org/10.1016/j.jcorp fin.2013.04.001

Angelovska J (2017) Investors' behaviour in regard to company earnings announcements during the recession period: evidence from the Macedonian stock exchange. Econ Res-Ekonomska Istrazivanja 30(1):647-660. https://doi.org/10.1080/1331677X.2017.1305768

Anwar S, Singh S, Jain PK (2017) Impact of cash dividend announcements: evidence from the Indian manufacturing companies. J Emerg Market Finance 16(1):29-60. https://doi.org/10.1177/09726 52716686238

Badan Pusat Statistik (2020) Laju Pertumbuhan PDB menurut Pengeluaran (Persen), 2020. https://www. bps.go.id/indicator/169/108/1/-seri-2010-laju-pertumbuhan-pdb-menurut-pengeluaran.html

Bhattacharya S (1979) Imperfect information, dividend policy, and "the bird in the hand" fallacy. Bell J Econ 27(1):8-10. https://doi.org/10.2469/dig.v27.n1.3

Chaabouni I (2017) Impact of dividend announcement of stock return: a study listed companies in the Saudi Arabia financial markets. Int J Inf Bus Manag 9(1):37-44. https://www.researchgate.net/publi cation/328582494_IMPACT_OF_DIVIDEND_ANNOUNCEMENT_ON_STOCK_RETURN_A_ STUDY_ON_LISTED_COMPANIES_IN_THE_SAUDI_ARABIA_FINANCIAL_MARKETS

Fabian A, Santoso EB (2020) Dividend announcement effect to market reaction in non-financial companies listed on indonesia stock exchange. J Account Entrep Financ Technol 1(2):57-67. https://doi. org/10.37715/jaef.v1i2.1467

Felimban R, Floros C, Nguyen A-N (2018) The impact of dividend announcements on share price and trading volume. J Econ Stud 45(2):210-230. https://doi.org/10.1108/jes-03-2017-0069

Frensidy B, Josephine I, Ignatius (2019) Price formation around dividend announcement date: empirical evidence in Indonesian stock exchange. Eur Res Stud J XXII(3):106-118. https://doi.org/10.35808/ ersj/1460

Godager E, Lia H, Kisser M (2019) What are the implications of dividend changes? An empirical study of dividend signaling in the Norwegian stock market. pp 193-197. http://hdl.handle.net/11250/ 2612204

Gul S, Ullah I, Gul H, Rasheed S (2020) The factors affecting dividend policy: empirical study from pharmaceutical's companies in Pakistan (PSX). Eur J Bus Manag Res 5(5):1-6. https://doi.org/10. 24018/ejbmr.2020.5.5.464

Herwany A, Febrian E, Anwar M, Gunardi A (2021) The influence of the COVID-19 pandemic on stock market returns in Indonesia stock exchange. J Asian Finance Econ Bus 8(3):39-47. https://doi.org/ 10.13106/jafeb.2021.vol8.no3.0039

Hossain M (2020) The effect of the Covid-19 on sharing economy activities. J Clean Prod. https://doi.org/ 10.1016/j.jclepro.2020.124782

Ibn-Mohammed T, Mustapha KB, Godsell J, Adamu Z, Babatunde KA, Akintade DD, Acquaye A, Fujii H, Ndiaye MM, Yamoah FA, Koh SCL (2020) A critical review of the impacts of COVID-19 on the 
global economy and ecosystems and opportunities for circular economy strategies. Resour Conserv Recycl 164(May 2020):105169. https://doi.org/10.1016/j.resconrec.2020.105169

Kadioglu E, Telceken N, Ocal N (2015) Market reaction to dividend announcement: evidence from Turkish stock market. Int Bus Res 8(9):83-94. https://doi.org/10.5539/ibr.v8n9p83

Khanal AR, Mishra AK (2017) Stock price reactions to stock dividend announcements: a case from a sluggish economic period. N Am J Econ Finance 42(June 2009):338-345. https://doi.org/10.1016/j. najef.2017.08.002

Liu J, Sarkar S, Kumar S, Jin Z (2018) An analysis of stock market impact from supply chain disruptions in Japan. Int J Product Perform Manag 67(1):192-206. https://doi.org/10.1108/IJPPM-06-2016-0104

Liu H, Manzoor A, Wang C, Zhang L, Manzoor Z (2020) The COVID-19 outbreak and affected countries stock markets response. Int J Environ Res Public Health 17(8):1-19. https://doi.org/10.3390/ijerp h17082800

Mestel R, Schleicher C, Gurgul H (2003) Stock market reactions to dividend announcements: Empirical evidence from the Austrian stock market. Financ Markets Portfolio Manag 17(3):332-350. https:// link.springer.com/content/pdf/10.1007/s11408-003-0304-1.pdf

Meza N, Báez A, Rodriguez J, Toledo W (2020) The dividend signaling hypothesis and the corporate life cycle. Manag Financ. https://doi.org/10.1108/MF-10-2019-0512

Modigliani F, Miller MH (1958) The cost of capital, corporation finance and the theory of investment. Am Econ Rev 48(3):261-297. http://www.jstor.org/stable/1809766

Mujib B, Candraningrat IR (2021) Capital market reaction to Covid-19 pandemic on LQ45 shares at Indonesia stock exchange (IDX). Am J Human Soc Sci Res 5(3):74-80. https://www.ajhssr.com/ volume-5-issue-03/

Ozo FK, Arun TG (2019) Stock market reaction to cash dividends: evidence from the Nigerian stock market. Manag Financ 45(3):366-380. https://doi.org/10.1108/MF-09-2017-0351

Pratama IKAD, Damayanthi IGAE, Dharmadiaksa IB, Suardana KA (2020) Capital market reaction to the 2019 Indonesian presidential election announcement results by the general election commission and constitutional court decision. Am J Human Soc Sci Res 04(01):286-291. https://www.ajhssr. com/volume-4-issue-1/

Putra IKTB, Badjra IB (2021) Open access abnormal return of stocks during stock split announcement (empirical study at Indonesia stock exchangein 2019). Am J Human Soc Sci Res 5(4):509-516

Sah RK (2015) Provisions Of presentation of "proposed dividend" in balance sheet: a comparison of companies act 2013 and accounting standard rules 2006. Abhinav Int Mon Refereed J Res Manag Technol 4(5):7-12. www.abhinavjournal.com

Schell D, Wang M, Huynh TLD (2020) This time is indeed different: a study on global market reactions to public health crisis. J Behav Exp Financ 27:100349. https://doi.org/10.1016/j.jbef.2020.100349

Sharma G (2017) Pros and cons of different sampling techniques. Int J Appl Res 3(7):749-752. www. allresearchjournal.com

World Health Organization (2020) WHO Timeline-Covid-19. https://www.who.int/news/item/27-042020-who-timeline---covid-19 